\title{
バキュロウイルス性中腸腺壊死症ウイルス $(\mathrm{BMNV}) の$ エーテル，食塩濃度および $\mathrm{pH}$ に対する抵抗性
}

\author{
桃山 和 夫* \\ (1989 年 6 月 5 日受付)
}

\begin{abstract}
Tolerance of Baculoviral Mid-gut Gland Necrosis Virus (BMNV) to Ether, $\mathrm{NaCl}$ Concentration and $\mathrm{pH}$
\end{abstract}

\author{
Kazuo Momoyama \\ Yamaguchi Prefectural Naikai Fisheries Experimental Station, Yamaguchi 754, Japan
}

(Received June 5, 1989)

Tolerance of $\mathrm{BMNV}$ to ether, $\mathrm{NaCl}$ concentration and $\mathrm{pH}$ was investigated by means of the infection method of the author using larval and post-larval kuruma shrimp, Penaeus japonicus. Test shrimp sampled on day 4 after water-borne inoculation were examined for nuclear hypertrophy of the mid-gut gland epithelial cells in fresh squash preparations under the dark field microscope. The results obtained are summerized as follows;

Ether: BMNV did not tolerate to $18 \mathrm{hr}$ treatment with ethyl ether at $4^{\circ} \mathrm{C}$.

$\mathrm{NaCl}$ concentration: $\mathrm{BMNV}$ was inactivated in $25 \% \mathrm{NaCl}$ solution within 10 hours and in $12.5 \% \mathrm{NaCl}$ solution within 24 hours. But it tolerated to $24 \mathrm{hr}$ treatment with $\mathrm{NaCl}$ solutions of $0-6.0 \%$.

$\mathrm{pH}$ : BMNV had low telerance to low $\mathrm{pH}$, and was inactivated in sea water adjusted to $\mathrm{pH}$ value of 1.0 within 10 minutes, 1.5 and 2.0 within 30 minutes, 2.5 within 60 minutes, and 3.0 and 4.0 within 180 minutes. Whereas the virus had high tolerance to high $\mathrm{pH}$, and was not inactivated by 180 minute exposure in sea water adjusted to $\mathrm{pH}$ values of $10.0-13.0$.

筆者はこれまでに，バキュロウイルス性中腸腺壊死症 ウイルス (BMNV) に対する消毒剤の不活化効果（桃山, 1989a)，紫外線や熱等の物理・化学的不活化（桃山, 1989b）について報告した。

今回，本ウイルスの性状をより明らかにすることを目 的として, ェーテル，食塩濃度掞よび $\mathrm{pH}$ に対する抵抗 性を, 前報と同様にクルマエビ稚仔を用いた感染実験 (MoMOYAMA and SANO, 1988) とより調べたので報告す る。

\section{材料および方法}

\section{1. 供試クルマエビ}

山口県内海栽培漁業センターで種苗生産されたミシス から P-4 (4 日令のポストラーバ) までのいずれかの発育 期にある健康な稚仔を用いた。これらの稚仔は, BMNV

* 山口県内海水産試験場
に対して高い感受性をもつことが (MоMOYAMA and SANO, 1989) により明らかにされている。

\section{2. 供試 BMNV 液}

サンプルビンに小分けされ, $-80^{\circ} \mathrm{C}$ で $3 \sim 4$ 年間凍結 保存されていた同一群由来の BMN の自然発病エビ $1 \mathrm{~g}$ (約 400 尾, 平均体重 $2.5 \mathrm{mg}$ ) 飞隇菌海水 $10 \mathrm{ml}$ を加兄 た後, Momoyama and SANo (1988) 飞従って調整され たホモジネート濾液 $(450 \mathrm{~nm})$ をウイルス液として用い た。

なお, 本ウイルス液のクルマエビ稚仔に対する浸漬接 種による感染力価は, クルマエビの発育期によって多少 異なるが, $10^{-5}$ から $10^{-7}$ の範囲にあった。

\section{BMNV 処理方法}

以下の手順に従った。 エーテル

石井 (1973) に涪ぼ準じた。すなわち，ウイルス液 $2 \mathrm{~m} l$ 
に隇菌海水 $6 \mathrm{~m} l$ を加えて混合後, $4 \mathrm{~m} l$ ずつ 2 本の試験 管に分注する。1 本に特級エチルエーテル $1 \mathrm{ml}$ を加え, 密栓して時々振とうしながら $4^{\circ} \mathrm{C}$ の冷蔵庫に保存する。 他の 1 本は対照としてェーテルを加えずに以下同様の操 作をする。1 8 時間後, 室温にもどして空気のバブリング によってェーテルを除く。

\section{食塩灌度}

予め $25^{\circ} \mathrm{C}$ の恒温水槽にセットして执いた 0 25\% (Table 2) の食塩水 $50 \mathrm{ml}$ に, ウイルス液 $0.5 \mathrm{ml}(25 \%$ 食塩水についてはウイルス液 $1.0 \mathrm{ml}$ ) を加えて混合後, 再び恒温水槽にもどして所定時間静置する。

\section{pH}

滅菌海水 $50 \mathrm{~m} l$ を入れた試験管に $\mathrm{N} / 100$ または $\mathrm{N} / 10$ の塩酸または水酸化ナトリウム溶液を加えて所定 (Table 3) の $\mathrm{pH}$ に調整した後, $25^{\circ} \mathrm{C}$ の恒温水槽にセット しておく。ウイルス液 $0.5 \mathrm{~m} l$ を加えて混合後再び恒温 水槽にもどして静置する。所定時間後, 直ちに予め求め て抢いた中和するのに必要な量の上記規定濃度の水酸化 ナトリウム溶液または塩酸を加えて中和し，作用を停止 する。

\section{4. 接種方法}

処理後 $500 \mathrm{ml}$ (食塩濃度 $25 \%$ 液で処理したものは $1 l$ ) の海水で稀釈されたウイルス液に 30 尾の供試エビを 2 時間浸漬して行った。

\section{BMNV の抵抗性の有無の判定方法}

接種された供試エビを水温 $25.5 \sim 30.2^{\circ} \mathrm{C} て ゙ ~ 4$ 日間飼 育後, 無作為に採取した 10 尾の生鮮中腸腺について, 暗視野観察法 (桃山, 1983) 飞より感染の有無を調べて抵 抗性の有無を判定した。

なお，供試エビの発育期には多少のバラッキが認めら れたが，各実験毎の主な発育期は，エーテル抵抗性試験 に対しては $\mathrm{P}-3$, 食塩濃度抵抗性試験に対してはミシス III 期と P-1, pH 抵抗性試験に対してはミシス II 期, III 期および P-4 がそれぞれ用いられた。

\section{結果および考察}

\section{エーテル}

エンベロープを有するウイルスは一般にリピド溶剤感 受性であると言われている(石井，1973)。BMNV は他 のバキュロウイルス (川瀬, 1976) と同様エンベロープを 持つことが確かめられて招り (SANO et. al., 1981), エー テル感受性についても陽性を示した (Table 1)。

\section{食塩濃度}

BMNV は食塩水 $25 \%$ 液では 10 時間以内に, $12.5 \%$
Table 1. Tolerance of BMNV to ethyl ether.

\begin{tabular}{cc}
\hline \hline Ether treatment & $\begin{array}{l}\text { Incidence of infection } \\
\text { (No. of shrimp infected/ } \\
\text { no. examined) }\end{array}$ \\
\hline Yes & $0 / 10$ \\
No & $10 / 10$ \\
\hline
\end{tabular}

Table 2. Tolerance of BMNV to various $\mathrm{NaCl}$ concentrations.

\begin{tabular}{ccccc}
\hline \hline & \multicolumn{4}{l}{ Exposure time (hour) at $25^{\circ} \mathrm{C}$} \\
\cline { 2 - 5 } $\begin{array}{c}\mathrm{NaCl} \\
\text { concentration } \\
(\%)\end{array}$ & $\begin{array}{l}\text { No. of shrimp } \\
\text { no. infected/ } \\
\end{array}$ & $\begin{array}{l}\text { Noxamined } \\
\text { no. }\end{array}$ & \\
\hline 25 & $10 / 10$ & $10 / 10$ & $0 / 10$ & $0 / 10$ \\
12.5 & $10 / 10$ & $10 / 10$ & $10 / 10$ & $0 / 10$ \\
6.0 & $10 / 10$ & $10 / 10$ & $10 / 10$ & $10 / 10$ \\
3.0 & $10 / 10$ & $10 / 10$ & $10 / 10$ & $10 / 10$ \\
0.3 & $10 / 10$ & $10 / 10$ & $10 / 10$ & $10 / 10$ \\
0 & $10 / 10$ & $10 / 10$ & $10 / 10$ & $10 / 10$ \\
\hline
\end{tabular}

液では 24 時間以内にそれぞれ不活化された (Table 2)。 しかし，それ以下の濃度では食塩濃度 0\%（実際には添 加したウイルス液中の塩類により, 約 $0.03 \%$ の塩分濃 度と計算される) においてる 24 時間活性を保持してお り，低塩分に対しては抵抗性を示した。

筆者は前報（桃山，1989b）に执いて，海水に懸濁され 濾紙上に滴下された本ウイルスの乾燥過程に打ける速や かな不活化には，ウイルスをとりまいている環境水の塩 分濃度の上昇が大きく関与しているのではないかと述べ た。今回の実験では, 飽和に近い $25 \%$ の食塩濃度（食 塩の $25^{\circ} \mathrm{C}$ に打ける溶解度は 26.43) では 3 時間以上, また, 海水の約 4 倍の濃度の $12.5 \%$ 食塩水では 10 時 間以上活性が保持されていた。本ウイルスの食塩濃度に 対する抵抗性は食塩の飽和点付近で急激に低下するよう に思われる。

\section{pH}

核多角体病やグラニュローシスなど陸上昆虫由来のバ キュロウイルスはアルカリに対しては比較的抵抗性で, ウイルスの精製には薄いアルカリ溶液で封入体を溶解す る方法が通常用いられている(川瀬, 1976)。封入体非形 成の BMNV も高い $\mathrm{pH}$ に対しては抵抗性が大きく, $\mathrm{pH} 13.0$ に暴露されてる 180 分間活性を保持していた (Table 3)。

しかし，本ウイルスは低い $\mathrm{pH}$ に対しては抵抗性は小 さく, $\mathrm{pH} 1.0$ では 10 分以内, 1.5 と 2.0 では 30 分以 内, 2.5 では 60 分以内, 3.0 と 4.0 では 180 分以内に 
Table 3. Tolerance of BMNV to various $\mathrm{pH}$.

\begin{tabular}{|c|c|c|c|c|}
\hline \multirow{3}{*}{$\mathrm{pH}$} & \multicolumn{4}{|c|}{ Exposure time (minute) at $25^{\circ} \mathrm{C}$} \\
\hline & 10 & 30 & 60 & 180 \\
\hline & \multicolumn{4}{|c|}{ No. of shrimp infected/no. examinec } \\
\hline 1.0 & $0 / 10$ & $0 / 10$ & & \\
\hline 1.5 & $4 / 10$ & $0 / 10$ & $0 / 10$ & \\
\hline 2.0 & $10 / 10$ & $0 / 10$ & $0 / 10$ & \\
\hline 2.5 & $10 / 10$ & $10 / 10$ & $0 / 10$ & $0 / 10$ \\
\hline 3.0 & $10 / 10$ & $10 / 10$ & $9 / 10$ & $0 / 10$ \\
\hline 4.0 & $10 / 10$ & $10 / 10$ & $10 / 10$ & $0 / 10$ \\
\hline 5.0 & $10 / 10$ & & $10 / 10$ & $10 / 10$ \\
\hline 8.0 & $10 / 10$ & & $10 / 10$ & $10 / 10$ \\
\hline 10.0 & $10 / 10$ & & $10 / 10$ & $10 / 10$ \\
\hline 11.0 & $10 / 10$ & & $10 / 10$ & $10 / 10$ \\
\hline 12.0 & $10 / 10$ & & $10 / 10$ & $10 / 10$ \\
\hline 13.0 & $10 / 10$ & & $10 / 10$ & $10 / 10$ \\
\hline
\end{tabular}

それぞれ不活化された。MOMOYAMA and SANO (1989) は, クルマエビ稚仔の BMNV に対する感受性は発育と ともに低下し, ゾェアから P-4 までは高い感受性を示す のに対して, P-8 ないし P-10 では著しく抵抗性となっ ていること, および本ウイルスは経口的に稚仔の体内に とり込まれる可能性が強いことを指摘した。また, クル マエビ稚仔の生理・生態的特性は P-10 前後 (体長 7 $10 \mathrm{~mm}$ ) を境として大きく変化することが知られている (倉田, 1972; 石岡, 1973)。クルマエビ稚仔の発育に伴う BMNV に対する抵抗性の増大に胃液の $\mathrm{pH}$ がどの程度 関与しているかは, 消化液中の不活化物質 (川瀬, 1976) の探索とともに今後の検討課題であろう。

\section{謝辞}

本研究を進めるにあたり貴重な御助言と本報告の御校 閲を賜った東京水産大学・佐野徳夫教授に厚くお礼申し
上ゲます。

なお, 本研究費の一部は水産庁・魚病対策技術開発研 究委託費によったことを付記して感謝する。

\section{引用文献}

石井慶蔵 (1973): ウイルス粒子の性状の検索法と群別. ウイルス実験学総論, 国立予防衛生研究所学友会編, 丸善, 東京, 472-478.

石岡宏子 (1973): クルマエビ人工種苗の生理生態に関す る研究. 南西水研研報, 6, 59-84.

川瀬茂実 (1976)：ウイルスと昆虫. 化学の領域選書 12, 南江堂, 東京, $312 \mathrm{pp}$.

倉田 博 (1972): クルマエビ栽培における種苗とその播 殖に関する諸原理について。南西水研研報, 5, 33-75. 桃山和夫 (1983)：クルマエビのバキュロウイルス性中腸 腺壊死症に関する研究一III, 仮診断法. 魚病研究, 17, 263-268.

桃山和夫 (1989a)：消毒剤によるバキュロウイルス性中 腸腺壊死症 (BMN) ウイルスの不活化効果. 魚病研 究, 24, 47-49.

桃山和夫 (1989b)：紫外線，日光，熱および乾燥による バキュロウイルス性中腸腺壊死症 (BMN) ウイルスの 不活化. 魚病研究, 24, 141-146.

Momoyama, K. and T. SANo. (1988): A method of experimental infection of kuruma shrimp larvae, Penaeus japonicus Bate, with baculoviral mid-gut gland necrosis (BMN) virus. J. Fish Diseases, 11, 105-111.

Momoyama, K. and T. Sano. (1989): Developmental stages of kuruma shrimp, Penaeus japonicus Bate, highly susceptible to baculoviral mid-gut gland necrosis (BMN) virus. $J$. Fish Diseases (in print).

Sano, T., T. Nishimura, K. Oguma, K. Momoyama and N. TAKENO (1981): Baculovirus infection of cultured kuruma shrimp, Penaeus japonicus in Japan. Fish Pathology, 15, 185-191. 